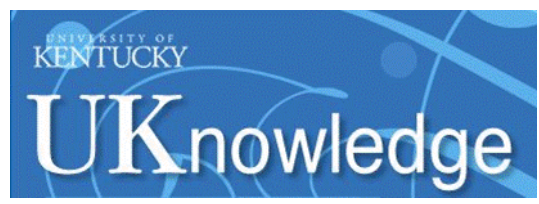

University of Kentucky

UKnowledge

$3-8-2021$

\title{
Young Children's Information-Seeking Practices in Center-Based Childcare
}

Sarah C. Barriage

University of Kentucky, sarah.barriage@uky.edu

Follow this and additional works at: https://uknowledge.uky.edu/slis_facpub

Part of the Library and Information Science Commons

Right click to open a feedback form in a new tab to let us know how this document benefits you.

\section{Repository Citation}

Barriage, Sarah C., "Young Children's Information-Seeking Practices in Center-Based Childcare" (2021). Information Science Faculty Publications. 93.

https://uknowledge.uky.edu/slis_facpub/93

This Article is brought to you for free and open access by the Information Science at UKnowledge. It has been accepted for inclusion in Information Science Faculty Publications by an authorized administrator of UKnowledge. For more information, please contact UKnowledge@lsv.uky.edu. 


\section{Young Children's Information-Seeking Practices in Center-Based Childcare}

\section{Digital Object Identifier (DOI)}

https://doi.org/10.1177/0961000620962164

\section{Notes/Citation Information}

Published in Journal of Librarianship and Information Science.

Barriage, S. (2021). Young children's information-seeking practices in center-based childcare. Journal of Librarianship and Information Science, 096100062096216. Copyright @ 2021. DOI: https://doi.org/ $10.1177 / 0961000620962164$

The copyright holder has granted the permission for posting the article here.

The document available for download is the author's post-peer-review final draft of the article. 


\section{Young Children's Information Seeking Practices in Center-Based Child Care}

\section{Introduction}

In the United States in 2016, children between the ages of 3 and 5 years of age who were not enrolled in kindergarten spent an average of 29.5 hours per week in non-parental care (U.S. Department of Education, 2017). Nearly $61 \%$ of these children spent at least a portion of this time in center-based child care, which includes preschools, Head Start programs, day care centers, and other early childhood programs (U.S. Department of Education, 2017). Research has demonstrated the long-lasting impact of high-quality center-based child care on a child's overall well-being, with positive long-term outcomes identified in areas such as employment rates, income levels, educational attainment, substance use, and involvement in the justice system (Campbell et al., 2012; Reynolds et al., 2011; Schweinhart et al., 2005). In the short-term, centerbased child care has been shown to support young children's cognitive, language, literacy, numeracy, communication, social, and other school readiness skills (Ansari and Winsler, 2012, 2016; Burchinal et al., 2000; Gormley et al., 2005; Lee, 2005; Loeb et al., 2007; Votruba-Drzal et al., 2013). Although center-based child care has been recognized as an important setting for the support and development of young children's emerging literacy practices and other school readiness skills, the ways in which center-based child care may also be a setting in which young children engage in information practices has rarely been addressed in the literature. This is despite the fact that, as Stewart (2016) notes, information seeking skills are increasingly being included in pre-kindergarten curriculum standards, indicating an acknowledgement by the educational community of the importance of information practices for children's learning and development. This study seeks to address this gap by examining young children's information seeking practices within the context of a child care center, using a combination of research methods that privilege the children's own perspectives of their activities and experiences. 


\section{Literature Review}

Practitioners and researchers in library and information science have explored the ways in which library collections and services can support both the children in center-based child care and their care providers. Typically, focus is placed on areas such as emergent literacy and other skills believed to contribute to children's school readiness. Examples of the ways in which libraries provide support for young children in center-based child care settings include: the provision of reading programs and story times at libraries specifically for children in child care (Arnold, 2002; Hinton and Amodio, 1995); providing story time outreach (Cahill, 2004; Hinton and Amodio, 1995; Ptacek, 2016) and literacy training (Fehrenbach, Hurford, and Fehrenbach, 1998; Ptacek, 2016) at child care centers; and sharing the library's collections with child care centers through visits from the library’s bookmobile (Hinton and Amodio, 1995) or temporary loans of portions of the library’s collection (Arnold, 2002; Bagley, 2000; Hinton and Amodio, 1995). Libraries also work to support child care providers by: promoting the use of library collections and services for professional development (Edwards and Thornton, 2013; Hinton and Amodio, 1995); providing lists of developmentally appropriate materials to use with children (Hinton and Amodio, 1995); creating and loaning story time kits that include books and related toys and activities for use with the children under their care (Smuda, 2002); and hosting workshops and other training sessions related to early childhood development (Arnold, 2002) and early literacy (Ghoting, Rogers, and Stotlz, 2017; Romero and Armstrong, 2017; Smuda, 2002). However, little attention has been paid to the ways in which young children's emerging information practices can be similarly supported in center-based child care settings, either by library services and collections or by their care providers.

\section{Young Children's Information Practices}


Spink and Heinstrom (2011) have argued that information behavior ${ }^{\mathrm{i}}$ emerges in early childhood, specifically somewhere between 3 and 5 years of age. Scholars have pointed to cognitive abilities such as information processing capacity, knowledge base, and affective orientations (Byrnes and Bernacki, 2013), as well as physical, language, and social development as factors that "set the foundation for information behaviour" (Spink and Heinstrom, 2011: 247). Although early childhood has been identified as a crucial time period in the development of competencies and skills underlying information behavior, young children (those eight years of age and younger) have received scant attention in the body of literature concerned with information needs, seeking, and use overall. This is especially true of children under six years of age, as the majority of research concerned with children and youth focuses on those of school age (Shenton, 2004b; Spink and Heinstrom, 2011), with such studies frequently conducted in school settings (e.g., Beautyman and Shenton, 2009; Cooper, 2002, 2004; Enochsson, 2005; Gross, 2006; Shenton and Dixon, 2003a, 2003b; Spink, Danby, Mallan et al., 2010). Schools offer a number of advantages for researchers interested in children and youth, primarily because these institutions offer ready access to a large number of children of various ages and backgrounds who are co-located for extended periods of time (Shenton, 2004a). However, as the majority of U.S. states do not require children to attend school until 6 years of age or older (Diffey and Steffes, 2017), alternative research locations must be identified in order to investigate the information behaviors of this younger population.

Writing in 2011, Spink and Heinstrom note that "we currently have no evidence of information behaviour in three-year-old children" (253). However, in recent years several researchers have included children three years of age or even younger in their investigations of information needs, seeking, and use. In this work, the home has increasingly been utilized as a 
research site. For example, Agarwal (2014) observed a single child's use of touch devices from 2 to 4 years of age for a variety of purposes, including playing games, using educational apps, and searching for and watching videos, often relying on her parents for assistance with her information seeking activities. Given et al. (2016) also examined young children's technology use in the home, using video recordings of 3- to 5-year-old children engaging with information technology either independently or in collaboration with family members. The children in this study made use of information technology such as computers, tablets, smart phones, and ereaders as part of their play and literacy and numeracy activities, also engaging in everyday life information activities (Given et al., 2016). Barriage and Searles (2015) also focused on the home as sites of information seeking activities, examining the questions girls 3-to 6-years of age asked of family members during everyday interactions.

Other work involving young children over 3 years of age also provides evidence of their existing information practices. For example, research has investigated children's understandings of the concept of 'information', demonstrating that these understandings change with age. In Shenton and Dixon's (2003a) study of children 4 to 18 years of age, children 6 years of age and older provided verbal articulations of their understanding of the concept of 'information', with older children providing more complex explanations than younger children. Although 4- and 5year-old participants did not provide verbal articulations of their understanding of this concept, some of the 5-year-old participants articulated their understanding through drawings, and children of all ages provided examples of ways information could be obtained (Shenton and Dixon, 2003a). This demonstrates that even though the word 'information' may not be one with which young children are familiar or that they can verbally define, they understand the fundamental underlying concepts. Children at this young age have also demonstrated their ability 
to categorize information, with kindergarten children organizing information in ways consistent with their own personal experiences and children in the fourth grade making use of categorizations that are more abstract and more closely resemble adult categorization schemes (Cooper, 2004). Young children have reported using a variety of information sources in meeting their own information needs, including books and computers (Havigerová and Haviger, 2014; McKechnie, 2006), television (Havigerová and Haviger, 2014), and other people (Shenton and Dixon, 2003b). In other research studies, young children have been observed making use of interpersonal interactions (Barriage \& Searles, 2015; Stewart, 2016), computers and handheld devices (Agarwal, 2014; Given et al., 2016), school resources (Beautyman and Shenton, 2009; Cooper, 2002; Gross, 2006), library catalogues (Creel, 2014), and search engines (Spink et al., 2010), although with varying levels of success and assistance required. Additionally, parents have reported that young children make use of a variety of resources in addressing their information needs, including interpersonal interactions, digital and print media, various institutions such as libraries and museums, and internal sources such as their imagination (Barriage, 2016a).

\section{Researching Information Practices with Young Children}

While young children's understanding of the concept of 'information' may only be emerging, such an understanding is not a prerequisite for children's participation in research investigating the ways in which they engage with information. Even those children in Shenton and Dixon's (2003a) work who did not provide verbal articulations of their understandings of ‘information' were nonetheless able to discuss information seeking strategies when it was described as a way of "finding out" something. Thus, the exclusion of children under 6 years of age from the information behavior literature is not because children this young do not engage in 
information activities, but rather reflects the failure of researchers to recognize and appreciate these activities, as well as the perceived difficulties that researching the information activities of such a young group of individuals may pose. As Julien et al. (2011) note, questionnaires and interviews are the most commonly used methods in information behavior research. Young children's emerging verbal (McKechnie, 2000; Xu et al., 2020) and literacy skills (Cooper 2002), as well as their developing cognitive abilities (Xu et al., 2020), have been noted as potential barriers to their participation in such research.

In other fields such as childhood studies, researchers have worked to develop research methods that enable the direct engagement of young children in research. This direct engagement offers the potential to enrich our understanding of children's experiences. As Dahl (2014) notes, children have unique perspectives that can add to our understanding of any phenomena that involves them in some way. By paying attention to children's experiences researchers can gain a better understanding of why they behave in the ways that they do (Greene and Hill, 2005). Many researchers who work with children have cited ethnography as an appropriate way to gain insight into children's experiences and to make room for the inclusion of children's voices within the research process (Corsaro, 2003; James, 2001; McKechnie, 2000). James (2001) advocates for researchers to go beyond mere observation in studying children's experiences, suggesting the incorporation of other, more child-centered activities in the research process. The use of concrete, task-centered activities (Barriage, 2018; James, Jenks, and Prout, 1998) in the interview setting has been shown to create a richer interaction between the researcher and the child (Danby, Ewing, and Thorpe, 2011) and may help to make the child more comfortable (Johnson, Hart, and Colwell, 2014).

\section{Conceptual Frameworks}

Information Seeking Practices 
In this study, young children and their information seeking activities are viewed through a sociocultural lens. Specifically, information seeking and other types of engagement with information are understood as being a part of social practices, "the concrete and situated activities of interacting people, reproduced in routine social contexts across time and space” (Rosenbaum, 1993: 239). The information practice approach has been positioned as distinct from the information behavior approach, in that it focuses on the sociocultural context in which people engage with information, rather than taking an individualistic, cognitive stance (Savolainen, 2007).

McKenzie (2003) has developed a model of information seeking practices that is used to guide this study. In McKenzie's model, four modes of information seeking have been identified - active seeking, active scanning, non-directed monitoring, and obtaining information by proxy (see Figure 1), as well as two phases of information seeking - connecting and interacting with information sources. In this model, information sources can take any number of forms, including other people and documents. McKenzie (2003) identifies a number of specific information practices within these four modes and two phases, including asking spontaneous and pre-planned questions, active observation, browsing, and receiving information from others.

\section{[ Insert Figure 1 here ]}

\section{Guided Participation}

In line with this socio-cultural approach to understanding children's engagement with information, this study also takes a socio-cultural approach to understanding children's development. Such approaches, heavily influenced by the work of Vygotsky (1978), view learning as a social process. Rogoff $(1990,2003)$ has extended Vygotsky's work in her conceptualization of cognitive development as guided participation. According to Rogoff 
(2003), learning and development are processes of "changing participation in the socio-cultural activities" of the communities to which children belong (11). This participation is guided by important individuals in children's lives, including parents, family members, and teachers, and involves children and their companions working together to achieve shared understanding of and structure participation in the activities of a child's community (Rogoff, 1990). According to guided participation, children learn and develop through observation and direct participation in community activities, through their interactions with others, and by engaging in community narratives and routines (Rogoff, 2003). This guidance can be provided through "face-to-face and side-by-side interaction as well as more distal arrangements of people's activities" (Rogoff, Baker-Sennett, Lacasa et al., 1995: 46). Guided participation is distinct from other sociocultural approaches to development in two ways. First, while the guidance of more competent or experienced others is consistent with Vygotsky's zone of proximal development, Rogoff (1990) argues that guided participation places more emphasis on children's active role in the development process. And secondly, guided participation focuses less on "explicit and even didactic dialogue that has characterized Vygotskian theory as well as American views of socialization" (Rogoff, 1990: 16), recognizing that learning also occurs in the routine, mundane activities of daily life.

\section{Research Objectives}

To date, the information practices of children 3 to 5 years of age in settings outside of the home or school have not been a focus of research. This is despite the fact that large numbers of children spend a significant amount of time in child care, including center-based child care settings. Additionally, research that is concerned with young children's information needs, seeking, and use has tended to rely on video recordings or reports from parents, caregivers, 
teachers, and other significant adults in children's lives about children's activities. While some attempts have been made to explore the ways in which young children understand the concept of 'information' and articulate strategies of information seeking, these studies have been limited to children of school age. The present study seeks to address the gaps in the literature identified above in considering the following research questions:

1. How do children 3-5 years of age define the concept of 'information'?

2. What information seeking activities do 3-5-year-old children engage in within a centerbased child care setting?

\section{Methods}

Setting

The research study used convenience sampling, taking place in a class of 3- to 5-year-old children (the 'Chickadee' ${ }^{\text {ii }}$ class) at a university-affiliated child care center in the northeastern United States. The Chickadee class is lead by a head teacher with the assistance of a full-time assistant teacher, part-time aides, and undergraduate fieldwork students. The child care center also has a class for children under 3 years of age.

\section{Participants}

The participants in this study included 13 of the 14 children in the Chickadee class and their assistant teacher. The child participants included two 3-year-olds, eight 4-year-olds, and three 5-year-olds ${ }^{\mathrm{iii}}$. Six of the participants were boys and seven of the participants were girls. Many of the children in the Chickadee class spoke languages in addition to English; eight of the children were observed speaking in a language other than English in the child care center, and one additional child disclosed that he speaks a language other than English at home. All thirteen children participated in each stage of the research study. 
After obtaining approval from the researcher's institutional review board to conduct this study, additional approval was obtained from the child care center's research director. Parental consent was obtained from the parents of all child participants, and assent was obtained from each child prior to the interviews and photo tours. Permission to use the children's photographs was obtained from the parents of nine children.

\section{Data Collection}

This study used an ethnographic approach to understanding children's information seeking in their day care setting. Accordingly, multiple methods of participatory qualitative data collection were used, including participant observation, interviews, child-led tours, and child-generated photography. Child-led tours and child-generated photography are types of task-centered activities that have been successfully used in previous research with young children (e.g., Einarsdottir, 2005; Green, 2012; Merewether, 2015; Robson and Mastrangelo, 2017; Templeton, 2020; Waller, 2014; Xu et al., 2020). Child-led tours are a type of "mobile interview" in which a child or a group of children lead the researcher through a physical space in response to some type of prompt by the researcher (Johnson, Hart, Colwell et al., 2014: 42). Child-generated photography similarly involves the children taking photographs in response to the researcher's prompt (Clark-Ibanez, 2008). In both of these methods, children are positioned as experts of their own realities and hold more power within the research interaction than they would in more traditional types of heavily researcher-led interviews (Einarsdottir, 2005; Green, 2012; Johnson, Hart, Colwell et al., 2014). These methods of data collection are also particularly advantageous when conducting research with young children as they decrease reliance on verbal communication, allowing children to draw on other means of communication to share their 
experiences with the researcher (Clark-Ibanez, 2008; Einarsdottir, 2005; Green, 2012; Johnson, Hart, Colwell et al., 2014).

Data collection for this research study proceeded as follows:

- Approximately thirty hours of observation of the children during their normal classroom routine over four months: In addition to directly observing and documenting via field notes the children's information practices in the classroom, the researcher was able to become familiar with the individual children, as well as the classroom language and culture.

- Initial semi-structured individual interviews with children: The children were asked about their understanding of the concept of 'information' and the strategies they use to satisfy gaps in their knowledge.

- Individual child-led photo tours of the child care classroom: The children were asked to take the researcher on a tour of the classroom and to talk about people and objects in the classroom that help them find out new things. The children used an iPhone in order to take pictures of these people and objects during the tour; only one of the children needed to be instructed on the use of this device to take pictures. The children wore a lapel microphone connected to a small voice recorder that fit in their pockets in order to record their responses during this photo tour.

- Unstructured individual photo-elicitation interviews with the children: The children were given physical copies of the photographs that they had taken during the photo tour and a photo album in which to put them. They were asked to identify the people and objects in the photographs and to explain how these people and objects help them find out new things. 
All interviews and photo tours were video- or audio-recorded, except for one child for whom parental consent for recording was not obtained and two children who did not assent to the recording of one of their research interactions. In these cases, notes were taken during the interviews. For more information about the methods used in this study, please see Barriage (2016b).

\section{Data Analysis}

Field notes and transcripts of child-led photo tours and interviews were analyzed for common themes related to information sources and seeking strategies via the constant comparative method, using open and axial coding (Charmaz, 2014). Content analysis (Rose, 2016) was used to analyze the children's photographs. The data gathered using the various methods described above were then examined holistically, with particular attention paid to recurring themes and any apparent contradictions that surfaced.

\section{Findings}

\section{Defining Information}

The majority of the children in this study indicated that they were not familiar with the word 'information,' and were not able to provide a definition of the concept when asked. Two of the children provided tentative definitions that do not match adult understandings of the concept. Jacob, age 5, stated "I think it's toys. Of course it's not toys." When asked why not, he replied "Because that doesn't sound like the word toys." Olivia, age 4, stated "It might mean something not nice." Gavin, age 3, did not provide an explanation of the concept but when asked if he was familiar with the word, he stated "I know it, but I don't know the word to call it." As the children were not familiar with the word 'information', other words and phrases were used in subsequent 
interviews, such as 'finding out new things' (consistent with the work of Shenton and Dixon, 2003b).

Ways of 'Finding Out New Things'

During the child-led photo tours, all thirteen children took photographs of people and objects in the classroom. In total, the children took 804 photographs. Duplicate photographs were removed before content analysis was completed, leaving 474 photographs. ${ }^{\text {iv }}$ Table 1 shows the results of the content analysis of these 474 photographs. The miscellaneous category includes photographs of objects that only one child photographed. Note that this table reflects all photographs taken by the children, not only those for which the child provided an accompanying verbal articulation of how the particular object(s) or person(s) contributed to their information seeking practices.

Table 1. Contents of photographs taken by participants

\begin{tabular}{|c|c|c|}
\hline Category & $\begin{array}{c}\text { Number of Photographs } \\
\text { Taken }\end{array}$ & $\begin{array}{c}\text { Number of Children Who } \\
\text { Took Photographs }\end{array}$ \\
\hline People & 111 & 10 \\
\hline Children & 30 & 4 \\
\hline Children \& Adults & 15 & 6 \\
\hline Teacher(s) & 11 & 1 \\
\hline Researcher & 3 & \\
\hline Other Adults & & \\
\hline Areas of the Child Care & & \\
Center & &
\end{tabular}




\begin{tabular}{|c|c|c|}
\hline Shelving & 30 & 7 \\
\hline Classroom & 20 & 4 \\
\hline Activity Tables & 19 & 6 \\
\hline Floor & 13 & 2 \\
\hline Hallway & 11 & 3 \\
\hline Tabletops & 9 & 2 \\
\hline Carpet Area & 7 & 3 \\
\hline Classroom Door & 5 & 3 \\
\hline Cubbies & 5 & 3 \\
\hline Classroom Library & 4 & 4 \\
\hline Interview Room & 2 & 1 \\
\hline Wall & 2 & 1 \\
\hline \multicolumn{3}{|l|}{ Objects } \\
\hline Toys & 66 & 10 \\
\hline Artwork \& Crafts & 26 & 7 \\
\hline Birthday Display & 17 & 5 \\
\hline Posters & 11 & 5 \\
\hline $\begin{array}{l}\text { Calendar \& Leader } \\
\text { Board }\end{array}$ & 9 & 6 \\
\hline Books & 8 & 5 \\
\hline Computer & 6 & 4 \\
\hline Air Conditioner & 6 & 4 \\
\hline Sensory Table & 5 & 2 \\
\hline
\end{tabular}




\begin{tabular}{|l|c|c|}
\hline \multicolumn{1}{|c|}{ Adults' Belongings } & 4 & 3 \\
\hline Miscellaneous & 12 & 7 \\
\hline Unidentifiable & 7 & 4 \\
\hline
\end{tabular}

"You use our brains": Finding out new things on one's own. Several of the children interviewed in this study described information seeking activities that they undertake on their own, without assistance from other people or pre-existing external information sources. For example, when asked how he finds out something he doesn't already know, Noah, age 4, replied "You use our brains." Jacob also described relying on his own skills in finding out something new, providing an example of a potential scenario in which he would need to do so: "Count on fingers. Like when I'm doing a math question and I don't know the answer." In both of these instances, Noah and Jacob described relying on their own existing knowledge and skills to address gaps in their knowledge.

Another means of finding out new things on one's own involved creating new sources of information that could be referred to in the future, as described by three of the children during the photo tours and photo-elicitation interviews. For example, after taking a photo of a fire alarm in the hallway of the child care center, Charlotte, age 5, stated "I got some photos of that because what if we don't know where it is? Then that will remind us" (see Figure 2). Similarly, Audrey, age 4, noted that she photographed the researcher "because I need to remember you." Both Charlotte and Audrey explicitly articulated the taking of photographs as a means of creating information sources for their own possible future information needs.

[ Insert Figure 2 here ] 


\section{"She helps me learn": Finding out new things through interactions with others.}

Interacting with and observing others was an important component of the Chickadees'

information practices, and was mentioned by the children during all stages of data collection.

People, including both children and adults, were the most frequently photographed category, and discussions of the role others played in helping the children find out new things were common.

Throughout data collection, the Chickadees highlighted the importance of their classmates in contributing to their information practices. As shown in Table 1, ten of the thirteen children photographed their classmates during the child-led photo tours; as Olivia explained, "I took a picture of Audrey because she helps me learn." The Chickadees contributed to the information practices of their peers through both interaction and observation. For example, during circle time one day, the researcher observed an instance of peers helping to fill knowledge gaps through informal interaction. After the teacher announced that the class would be having burgers for lunch that day, Rachel, age 5, asked "What's a burger?". The teacher did not respond, so Rachel repeated her question to Charlotte. Charlotte explained that a burger is "two buns with something in the middle." In addition to asking specific questions of their peers, the Chickadees also engaged in observation of their classmates as a means of finding out new things. For example, in response to something Maria, age 3, said while picking out books to read on the carpet, Rachel gave Maria a thumbs up. Rachel held her hand up for an extended period of time while Maria mimicked her action, maintaining the gesture until Maria successfully produced a thumbs up. As these examples illustrate, children acted as sources of information for their peers within their everyday interactions and were identified by their peers as such.

The Chickadees also discussed ways in which the adults in the child care center contributed to their information practices. Asking the teacher was a frequently cited strategy for 
fulfilling information needs, and the children took many pictures of the primary teacher, as well as the student teachers and the researcher. Noah explained that the student teachers "teach me a lot of things," and in reference to the researcher stated, "You teach me... a lot of new things... while you chat with me." The Chickadees frequently took advantage of opportunities to ask the adults present in the day care center questions about a variety of topics, sometimes related to the formal curriculum of the daycare but often related to their own curiosities. For example, after one of the teacher's aides arrived at the child care center with a knee injury, Audrey and Maria asked many questions about her knee brace, crutches, and the x-rays she had done at the hospital. These examples demonstrate the importance of informal interactions with teachers and other adults to the Chickadees' information seeking practices.

"This helps me find out everything": Finding out new things through classroom resources, activities and routines. In addition to responding to children's questions, the classroom activities and routines implemented by the teachers also contributed significantly to the Chickadees' information practices. Many of these activities and routines were part of circle time, specific periods throughout the day when the Chickadees sat in a circle on the carpet and participated in various didactic activities led by the head teacher. Although the Chickadees did not directly name circle time as an opportunity to address their knowledge gaps, they frequently photographed things in the classroom that highlight the importance of this routine to their information practices. For example, as shown in Table 1, six of the children photographed the classroom calendar, a resource that was used in circle time on a daily basis. The teacher used the calendar to teach numbers, days of the week, years, and, as Lily, age 3, noted in her description of the calendar below, weather and seasons (see Figure 3). The calendar also served as a means of noting the Chickadees' birthdays: 
This helps me find out what weather it is... [pauses and examines photographs] These two help me find out what season it is. . This helps me find out everything 'cause this is the calendar. . So it's today, this day [points at calendar]. And [classmate]'s birthday is here. So that's why he's wearing a crown.

\title{
[ Insert Figure 3 here ]
}

The Chickadees also photographed other posters, artwork, and displays that were on the walls of the classroom, and identified how these items contributed to the information practices of both themselves and others. For example, in discussing a display on the classroom wall indicating each Chickadee's birth date and age, Audrey explained that these were on the wall "so the library teacher knows we are four or three or five." Other photographed items included a poster illustrating the main food groups and ideal portion sizes (see Figure 4), a poster demonstrating how to write the letters of the alphabet (see Figure 5), and the children's artwork (see Figure 6).

\author{
[ Insert Figure 4 here ] \\ [ Insert Figure 5 here ] \\ [ Insert Figure 6 here ]
}

Other aspects of classroom routine that the children photographed and discussed as part of their information practices included toys (see Figure 7), books (see Figure 8), and the classroom computer. Interestingly, the children were typically not allowed to use the computer but observed the teacher using it on many occasions. Rachel offered the following account of how the teachers used the computer as an information resource: 
Interviewer: So only the teachers use the computer?

Rachel: Yeah

Interviewer: Chickadees never use it?

Rachel: Yeah

Interviewer: What do the teachers use it for?

Rachel: For, for like sometime make some playdough and make some new things and check the temperature outside to go outside to play

[ Insert Figure 7 here ]

[ Insert Figure 8 here ]

Summary of findings. The majority of the children in this study did not provide definitions of the concept of 'information'; those definitions that were provided do not fit within adult understandings of the concept. In a traditional interview setting, some of the children described strategies that could be used to address gaps in their knowledge, including asking questions of others and figuring it out on one's own. When given the opportunity to photograph items and people in the child care center and to talk about those photographs, the children articulated more and more varied strategies of finding out new things. These included engaging with text- and image-based posters and displays in the classroom, books, toys, teachers, classmates, and the computer, and observing others' activities in the classroom. Some of the children also discussed their photographs as sources of information, separate from the people and items that these photographs depicted. 


\section{Discussion}

This study examined the ways in which 3- to 5-year-old children define the concept of information and engage in information seeking activities within the context of their center-based child care classroom. While none of the children provided definitions that reflected an understanding of the term 'information', consistent with prior research in this area (e.g., Shenton and Dixon, 2003a), many took pictures of and articulated ways in which they engaged with people and objects within the child care center as part of their information seeking activities. Using photo tours and photo-elicitation, the children described engaging with information in many different ways, including interacting with teachers, observing classmates, playing with toys, reading books, viewing posters, and creating artwork. The information seeking activities described by the children were largely consistent with those the researcher observed the children engaging in within the day care classroom. These activities spanned the modes and phases of information seeking identified by McKenzie (2003) and reflected the processes of guided participation as outlined by Rogoff (1990, 2003).

The ways in which the children in the Chickadee class described finding out new things included information seeking activities that are consistent with prior research focused on children's information practices, as well as activities that go beyond those explored in previous research. For example, the Chickadees described finding out new things on their own by making use of their existing knowledge and skills. This is consistent with prior research in which parents have described their children seeking information via internal sources, such as their imagination or by trying new things (Barriage, 2016a). The Chickadees also described finding out new things through interactions with others, including talking with and observing others. Other people with whom the Chickadees interacted and thereby found out new things included not only their 
teachers but also their peers. Other people, including teachers, family members, and peers, have been noted as important sources of information through direct interactions and observation in prior research with children (e.g., Barriage and Searles, 2015; Shenton and Dixon, 2003b; Stewart, 2016). Additionally, the Chickadees described finding out new things through classroom resources, activities, and routines, photographing and discussing ways in which the classroom environment contributed to their information seeking practices. Similarly, Robson and Mastrangelo (2017) report how the environment can act as a "third teacher" in a classroom, with the spaces and materials physically present in the classroom assisting children in their learning. However, such an approach to understanding the role of the environment in supporting young children's information seeking practices has not been well articulated in the literature.

Interestingly, while digital technology has dominated much discussion of children's information practices in other settings (e.g., Agarwal, 2014; Given et al., 2016; Spink et al., 2010), such technology was discussed very little in the Chickadees' accounts of their information seeking. In this particular child care setting, children did not make frequent use of technology in addressing their information needs. As Rachel noted above, the computer in the Chickadees' classroom was not made available to the children for their use; instead, it was used by teachers for tasks such as checking the weather to determine if the children could go outside to play and for finding ideas for classroom activities. And although other devices such as iPads were occasionally brought into the classroom for brief periods of play, they were not mentioned by any of the children when asked to describe ways in which they find out new things. While contemporary discourse surrounding young children in today's society is permeated with references to them as "digital natives" (Prensky, 2001) or as belonging to the "iGen" (Twenge, 2017) or the "digital generation" (Jukes, McCain, and Crockett, 2010), technology does not 
necessarily dominate all of young children's environments and everyday life situations. It is entirely possible that if the children were asked to talk about their information seeking at home that technology would have played a more prominent role in their reports of their activities. However, while focusing on children's use of technology is an important and necessary area of research, it does not lessen the importance of understanding children's interactions with physical documents, other people, and other everyday life, non-technological experiences and the environments in which these interactions and experiences occur. As the Chickadees' reports indicate, these experiences can be integral to their developing information practices.

\section{Implications for Practice}

By developing an understanding of children's perspectives regarding any phenomena that impacts them, a more complete picture of these phenomena can be constructed (Dahl, 2014). A more fully developed understanding of young children's information practices can be used to inform both child care and information service provision. As has been noted by multiple scholars, adults who are in a position to make decisions related to the provision of information to children may not actually have an accurate picture of these children's information needs (Bates, 1996; Shenton, 2010). One approach to rectifying this situation has been outlined by Agosto (2020). In reference to library services specifically, Agosto (2020) has advocated for the adoption of a "teen-centered approach" that takes into account youths" "thoughts, behaviors, needs, and preferences" (p. 4) in providing services for this population. She puts forward a threepronged approach to achieving such teen-centeredness, which involves conducting research that includes youth as participants, incorporating the findings of such research into the design and implementation of library services, and directly eliciting input from youth at the local level when designing and implementing such services (Agosto, 2020: 3-4). Although in her writing Agosto 
(2020) focuses specifically on adolescents, the described shifts in thinking about and serving youth apply equally well to young children.

Increasing young children's engagement in research related to their information needs and information seeking practices can increase both the quantity and quality of relevant research findings, allowing for greater accuracy in our collective understanding of children's information practices and the ways in which these information practices can be supported by both child care providers and information professionals. This expanded knowledge can influence many aspects of information service and child care provision. For example, relevant research findings that prioritize children's perspectives can be used to better inform collection development, reference services, and programs in libraries, as well as the resources and activities available to children in relevant child care contexts, that better meet children's needs and preferences. This applies to both scholarly research that involves children as research participants, as well as elicitations of children's perspectives by information or child care professionals as part of their professional practice. Examples of the latter include children's direct participation in collection development (Plemmons, 2017) and planning and implementing events and programming (Wilson, 2018), while potential examples of the former could include modifying libraries' policies and physical layouts based on findings that highlight the importance of social interactions for children's information seeking (Taylor et al., 2019) and library use activities (Xu et al., 2020).

In the case of young children's information practices in center-based child care, McKenzie's (2003) model of information practices provides a framework through which child care providers and library staff can intentionally guide children's participation (Rogoff, 1990, 2003 ) in the information activities of their communities. These professionals can work to aid children in both connecting and interacting with information and information sources available in 
the day care context. Importantly, the findings of this study have demonstrated the importance of both didactic and nondidactic interactions with adults and peers, classroom resources, activities and routines, as well as strategies children use in figuring out the answers to their information needs independently of external resources. The children articulated a diverse range of information seeking strategies; one was not necessarily more important than the others. Continuing to provide a range of experiences within the day care setting that allow for both intentional and serendipitous engagement with information is crucial in supporting children's information seeking. Acknowledging the important role that center-based child care settings can play in developing young children's information seeking practices is a crucial first step in developing methods of prioritizing and supporting the development of such information practices.

\section{Limitations}

This study took place in a single classroom of a university-affiliated child care center and thus made use of convenience sampling (Saumure and Given, 2008). Additionally, although demographic information was not collected, the center serves a population that is relatively homogenous in terms of the families' socio-economic status and parents' education level. Both of these factors limit the transferability of the findings to other center-based child care contexts.

The nature of the participatory data collection methods used in this study, specifically their potential to afford the child participants more control over what was discussed during interactions with the researcher, can in some cases be viewed as a limitation. The children may have taken pictures and/or shown the researcher areas of the child care center for reasons unrelated to the researcher's aims. For example, the children did not always articulate the ways in which photographed objects such as the air conditioner or adults' belongings relate to their 
information seeking practices. Additionally, the photographs the children took during the photo tours were limited to those objects and people that were physically present at the time of the tours. Finally, after creating the photo albums of their photographs, some of the children showed their photographs to their teachers and their classmates while on the playground. As the child-led photo tours and photo-elicitation interviews took place over several weeks, this potentially influenced the decisions of children who subsequently participated regarding who and what to photograph.

\section{Future Research Directions}

Future research should continue to explore young children's information practices in a wider range of center-based child care contexts, including those that are more diverse in terms of the race and socio-economic status of the children attending the centers, the geographic locations of the child care centers, and the types of approaches or philosophies underpinning care provision. Comparative approaches might be particularly fruitful in understanding the impact of such characteristics on young children's information practices. Future research should also investigate the information practices of young children in child care centers that have existing relationships with local public library services and information service providers.

Future research endeavors in this area should also focus on methodological innovations that enable researchers to encourage the direct participation of young children in the research process. The research described here offers one example of a set of methods that were successfully used to explore young children's information practices within a child care context. However, there are many other task-centered activities (Barriage, 2018) and other means of eliciting young children's views that can be used in research with young children, and it is possible that approaches different from those described here may be better suited for exploring 
information practices with this population and within this context. By using different approaches to data collection than those typically used in information behavior research conducted with adults, researchers can encourage young children to share their perspectives and experiences, both in formal and informal research contexts.

\section{Conclusion}

This study is the first step in creating a comprehensive picture of young children's information practices within a center-based child care setting. The findings of this study have important implications for child care providers, library staff involved in children's services, and researchers interested in the information practices of young children. This study has provided new insights into young children's information seeking practices in center-based child care, a setting that has been relatively unexplored in research in this area to date, using methods that privilege children's perspectives of their own activities and experiences.

As James (2007) states, "giving voice to children is not simply or only about letting children speak; it is about exploring the unique contribution to our understanding of and theorizing about the social world that children's perspectives can provide" (p. 262). By considering children's reports of their information activities in conjunction with existing theories of information practices and child development, our understanding of children's information practices can gain both depth and breadth. However, including young children in research on its own is not enough. Such research must also be incorporated into professional practice, along with the views of the children who make use of local services (Agosto, 2020). By doing so, a child-centered approach to information services as described by Agosto (2020) can be achieved. 


\section{References}

Agarwal NK (2014) Use of touch devices by toddlers or preschoolers: Observations and findings from a single-case study. In Bilal D and Beheshti J (eds) New Directions in Children's and Adolescent's Information Behavior Research. Bingley: Emerald, pp. 3-37.

Agosto D (2020) Envisaging young adult librarianship from a teen-centered perspective. In: Bernier A (ed) Transforming Young Adult Services (2 ${ }^{\text {nd }}$ ed). Chicago: ALA-Neal Schuman, pp. 3-15.

Ansari A and Winsler A (2012) School readiness among low-income, Latino children attending family childcare versus centre-based care. Early Child Development \& Care 182(11): 1465-1485. DOI: 10.1080/03004430.2011.622755.

Ansari A and Winsler A (2016) Kindergarten readiness for low-income and ethnically diverse children attending publicly funded preschool programs in Miami. Early Childhood Research Quarterly 37: 69-80. DOI: 10.1016/j.ecresq.2016.06.002.

Arnold R (2002) Coming together for children: A guide to early childhood programming. Journal of Youth Services in Libraries 15(2): 24-30.

Bagley NE (2000) Making connections: Outreach to preschoolers through satellite library collections. Journal of Youth Services in Libraries 13(3): 16-18.

Barriage S (2016a) “Talk, talk and more talk": Parental perceptions of young children's information practices related to their hobbies and interests. Information Research 21(3). Barriage S (2016b) Using child-centered methods to explore young children's information experience. In: iConference2016 Proceedings, Philadelphia, PA, 20-23 March 2016, pp. $1-7$.

Barriage S (2018) Task-centered activities as an approach to data collection in research with children and youth. Library \& Information Science Research 40(1): 1-8. 
Barriage S and Searles DK (2015) Astronauts and sugar beets: Young girls' information seeking in family interactions. In: Proceedings of the Association for Information Science and Technology, St Louis, MO, 6-10 November2015, pp. 1-10.

Bates MJ (1996) Learning about your users' information needs: A key to effective service. In: The Fifth Pacific Islands Association of Libraries and Archives Conference (ed A Cohen), pp. 5-12. Federated States of Micronesia: Pacific Islands Association of Libraries and Archives.

Beautyman W and Shenton AK (2009) When does an academic information need stimulate a school-inspired information want? Journal of Librarianship \& Information Science 41(2): 67-80. DOI: $10.1177 / 0961000609102821$

The behaviour/practice debate: A discussion prompted by Tom Wilson's review of Reijo Savolainen's Everyday information practices: A social phenomenological perspective. Lanham, MD: Scarecrow Press, 2008 (2009) Information Research 14(2). Available at: http://InformationR.net/ir/14-2/paper403.html

Burchinal MR, Roberts JE, Riggins R, Zeisel SA, Neebe E and Bryant D (2000) Relating quality of center-based child care to early cognitive and language development longitudinally. Child Development 71: 339-357. DOI: 10.1111/1467-8624.00149

Byrnes JP and Bernacki ML (2013) Cognitive development and information behavior. In: Beheshti J and Large A (eds) The Information Behavior of a New Generation. Lanham: Scarecrow Press, pp. 23-43.

Cahill M (2004) Meeting the early literacy needs of children through preschool outreach storytime programs. Knowledge Quest 33(2): 61-62.

Charmaz K (2014) Constructing Grounded Theory ( $2^{\text {nd }}$ ed). Thousand Oaks: Sage. 
Clark-Ibanez M (2008) Gender and "being bad": Inner-city students' photographs. In: Thomson P (ed) Doing Visual Research with Children and Young People. New York: Routledge, pp. 95-113.

Cooper LZ (2002) A case study of information-seeking behavior in 7-year-old children in a semistructured situation. Journal of the American Society for Information Science \& Technology 53(11): 904-922. DOI: 10.1002/asi.10130

Cooper L (2004) The socialization of information behaviour: A case study of cognitive categories for library information. Library Quarterly 74(3): 299-336.

Corsaro W (2003) We're Friends, Right? Inside Kids' Culture. Washington, DC: Joseph Henry Press.

Creel S (2014) Interface design: The impact of images and catalog organization on the information retrieval of children ages five to eight while subject browsing. In: Bilal D. and Beheshti J (eds) New Directions in Children's and Adolescents' Information Behavior Research. Bingley: Emerald Group, pp. 265-293.

Dahl TI (2014) Children as researchers: We have a lot to learn. In: Melton GB, Ben-Arieh A, Cashmore J, Goodman GS and Worley NK (eds) The SAGE Handbook of Child Research. Los Angeles: Sage, pp. 593-618.

Danby S, Ewing L, and Thorpe K (2011) The novice researcher: Interviewing young children. Qualitative Inquiry 17: 74-84. DOI: 10.1177/1077800410389754.

Diffey L and Steffes S (2017) Age requirements for free and compulsory education: 50-state review. Education Commission of the States. Available at: https://www.ecs.org/wp$\underline{\text { content/uploads/Age_Requirements_for_Free_and_Compulsory_Education-1.pdf }}$ 
Edwards MM and Thornton E (2013) Library outreach: Introducing campus childcare providers to the academic library. Education Libraries 36(2): 4-16.

Einarsdottir J (2005) Playschool in pictures: children's photographs as a research method. Early Child Development \& Care 175(6): 523-542.

Enochsson A (2005) The development of children's Web searching skills - a non-linear model. Information Research 11(1).

Fehrenbach LA, Hurford DP and Fehrenbach CR (1998) Developing the emergent literacy of preschool children through a library outreach program. Journal of Youth Services in Libraries 12(1): 40-45.

Ghoting S, Rogers P and Stoltz D (2017) Building bridges to early childhood educators. Children \& Libraries 15(4): 36-37.

Given LM, Winkler DC, Willson R, Davidson C, Danby S, and Thorpe K (2016) Watching young children 'play' with information technology: Everyday life information seeking in the home. Library \& Information Science Research 38(4): 344-352.

Gormley WT, Gayer T, Phillips D and Dawson B (2005). The effects of universal pre-K on cognitive development. Developmental Psychology 41: 872-884. DOI: 10.1037/00121649.41.6.872

Green C (2012) Listening to children: Exploring intuitive strategies and interactive methods in a study of children's special places. International Journal of Early Childhood 44(3): 269285.

Greene S and Hill M. (2005) Researching children's experience: Methods and methodological issues. In: Greene S and Hogan D (eds) Researching Children's Experience: Methods and Approaches. Thousand Oaks: Sage, pp. 1-21. 
Gross M (2006) Studying Children's Questions: Imposed and Self-Generated Information Seeking at School. Lanham: Scarecrow Press.

Havigerová J and Haviger J (2014) Where preschool children acquire information about a topic that they enjoy: Giftedness-based study. Procedia - Social and Behavioral Sciences 112(7): 219-224.

Hinton MJ and Amodio S (1995) The public library and the day care center: A Long Island survey. Journal of Youth Services in Libraries 8(2): 173-188.

James A (2001) Ethnography in the study of children and childhood. In: Atkinson P, Coffey A, Delamont S, Lofland J and Lofland L (eds) Handbook of Ethnography. Thousand Oaks: Sage Publications, pp. 246-257.

James A (2007) Giving voice to children's voices: Practices and problems, pitfalls and potentials. American Anthropologist 109(2): 261-272.

James A, Jenks C and Prout A (1998) Theorizing Childhood. Cambridge: Polity Press.

Johnson V, Hart R, and Colwell J (2014) Steps to Engaging Young Children in Research (Vol. 1). Brighton: Education Research Center, University of Brighton

Johnson V, Hart R, Colwell J, West A and Carvalho X (2014) Academic background and guidance on steps to engaging young children in research. In Johnson V, Hart R and Colwell J (eds) Steps to Engaging Young Children in Research (Vol. 1). Brighton: Education Research Center, University of Brighton, pp. 15-66.

Jukes I, McCain T, and Crockett L (2010) Understanding the Digital Generation: Teaching and Learning in the New Digital Landscape. Vancouver: 21st Century Fluency Project. 
Julien H, Pecoskie JL and Reed K (2011) Trends in information behavior research, 1999-2008: A content analysis. Library \& Information Science Research 33(1): 19-24. DOI: 10.1016/j.lisr.2010.07.014

Lee K (2005) Effects of experimental center-based child care on developmental outcomes of young children living in poverty. Social Service Review 79(1): 158-180.

Loeb S, Bridges M, Bassok D, Fuller B and Rumberger RW (2007) How much is too much? The influence of preschool centers on children's social and cognitive development. Economics of Education Review 26: 52-66. DOI: 10.1016/j.econedurev.2005.11.005

McKechnie L (EF) (2000) Ethnographic observation of preschool children. Library \& Information Science Research 22(1): 61-76. DOI: 10.1016/S0740-8188(99)00040-7

McKechnie L (EF) (2006) "Spiderman is not for babies" (Peter, 4 years): The "boys and reading problem" from the perspective of boys themselves. Canadian Journal of Information and Library Science 30(1/2): 57-67.

McKenzie P (2003) A model of information practices in accounts of everyday life information seeking. Journal of Documentation 59(1): 19-40. DOI: 10.1108 /00220410310457993

Merewether J (2015) Young children's perspectives of outdoor learning spaces: What matters? Australasian Journal of Early Childhood 40(1): 99-108. DOI:

$10.1177 / 183693911504000113$

Plemmons A (2017) Empowering student voice in the library. Available at: http://www.alsc.ala.org/blog/2017/11/empowering-student-voice-library Prensky M (2001) Digital natives, digital immigrants: Part 1. On the Horizon 9(5): 1, 3-6. Ptacek B (2016) Early literacy and the public library: An opportunity of a lifetime (of reading). Public Library Quarterly 35(4): 338-343. DOI: 10.1080/01616846.2016.1245007 
Reynolds AJ, Temple JA, Ou S-R, Arteaga IA and White BAB (2011) School-based early childhood education and age-28 well-being: Effects by timing, dosage and subgroups. Science 333(6040): 360-364. DOI: 10.1126/science.1203618

Robson K and Mastrangelo S (2017) Children's views of the learning environment: A study exploring the Reggio Emilia principle of the environment as the third teacher. Journal of Childhood Studies 42(2): 1-16.

Rogoff B (1990) Apprenticeship in Thinking: Cognitive Development in Social Context. New York: Oxford University Press.

Rogoff B (2003) The Cultural Nature of Human Development. New York: Oxford University Press.

Rogoff B, Baker-Sennett J, Lacasa P and Goldsmith, D (1995) Development through participation in sociocultural activity. New Directions for Child Development 67: 45-65.

Romero L and Armstrong LA (2017) Sharing the secret sauce: Engaging early childhood educators in library storytime practices. Children \& Libraries 15(4): 8-11.

Rose G (2012) Visual Methodologies: An Introduction to Researching with Visual Materials (3rd ed.). Thousand Oaks: Sage Publications.

Rosenbaum H (1993) Information use environments and structuration: Towards an integration of Taylor and Giddens. In: Proceedings of the $56^{\text {th }}$ Annual Meeting of the American Society for Information Science (ed S Bonzi), Columbus, OH, 24-28 October 1993, pp. 235-245. Medford, NJ: Learned Information.

Saumure K and Given LM (2008) Convenience sample. In: Given LM (ed) The SAGE Encyclopedia of Qualitative Research Methods. Thousand Oaks: SAGE Publications, p. 125. DOI: $10.4135 / 9781412963909 . n 68$ 
Savolainen R (2007) Information behavior and information practice: Reviewing the 'umbrella concepts' of information-seeking studies. Library Quarterly 77(2): 109-132. DOI: $10.1086 / 517840$

Schweinhart LJ, Montie J, Xiang Z, Barnett WS, Belfield CR and Nores M (2005) Lifetime Effects: The HighScope Perry Preschool Study Through Age 40. Ypsilanti, MI: HighScope Press

Shenton AK (2004a) Information-seeking research in schools: Opportunities and pitfalls. Aslib Proceedings 56(3): 180-186.

Shenton AK (2004b) Research into young people's information-seeking: Perspectives and methods. Aslib Proceedings 56(4): 243-254.

Shenton AK (2010) Etic, emic, or both? A fundamental decision for researchers of young people's information needs. New Review of Children's Literature \& Librarianship 16: 54-67. DOI: 10.1080/13614541.2010.503747

Shenton AK and Dixon P (2003a) Just what is information anyway? Some findings of research with school pupils. Education Libraries Journal 46(3): 5-14.

Shenton AK and Dixon P (2003b) Youngsters' use of other people as an information-seeking method. Journal of Librarianship \& Information Science 35(4): 219-233. DOI: $10.1177 / 0961000603035004002$

Smuda J (2002) Project LEAP: Cuyahoga County Public Library's investment in literacy for young children. Journal of Youth Services in Libraries 15(2): 20-23.

Spink A, Danby S, Mallan K and Butler C (2010) Exploring young children's web searching and technoliteracy. Journal of Documentation 66(2): 191 - 206. 
Spink A and Heinstrom J (2011) Information behavior development in early childhood. In A. Spink A and Heinstrom J (eds), New Directions in Information Behavior. Bingley: Emerald Group Publishing, pp. 245-256.

Stewart S (2016) Understanding the information seeking of pre-kindergarten students: An ethnographic exploration of their seeking behaviors in a preschool setting. $\mathrm{PhD}$ Thesis, University of North Texas, USA.

Taylor JB, Hora A and Krueger KS (2019) Self-selecting books in a children's fiction collection arranged by genre. Journal of Librarianship and Information Science 51(3): 852-865. DOI: $10.1177 / 0961000617743088$

Templeton TN (2020) 'That street is taking us to home': Young children's photographs of public spaces. Children's Geographies 18(1): 1-15. DOI: 10.1080/14733285.2018.1550573

Twenge J (2017) iGen: Why Today's Super-Connected Kids are Growing Up Less Rebellious, More Tolerant, Less Happy - And Completely Unprepared for Adulthood. New York: Atria Books.

United States Department of Education, National Center for Education Statistics (2017) Digest of education statistics. Available at: https://nces.ed.gov/programs/digest/ current tables.asp

Vygotsky L (1978) Mind in Society: The Development of Higher Psychological Processes. Cambridge: Harvard University Press.

Waller T (2014) Voices in the park: Researching the participation of young children in outdoor play in early years settings. Management in Education 28(4): 161-166. DOI: $10.1177 / 0892020614547488$ 
Wilson A (2018). Libraries as learning centers: Changing the culture of your library. Available at: http://edublog.scholastic.com/post/libraries-learning-centers-changing-culture-yourlibrary?

Xu J, Wang P, Sturm BW and Wu Y (2020) How preschool children think about libraries: Evidence from six children's libraries in China. Journal of Librarianship \& Information Science 52(2): 428-440. DOI: 10.1177/0961000618818887

\footnotetext{
i 'Information practices' and 'information behavior' are two terms used to describe the ways in which people engage with information (Savolainen, 2007). Information behavior is the predominant lens through which people's engagement with information has been understood in the North American context. Generally, information behavior denotes a psychological orientation to understanding people's engagement with information, while information practices denotes a sociological orientation ("Behaviour/practice debate," 2009). The phrase 'information practices' is used to describe the findings of this study, in line with its socio-cultural orientation and the use of McKenzie's (2003) model of information practices. The phrase 'information behavior' is used in reference to reviewed literature that has made use of this term, as well as the large body of literature concerned with people's engagement with information more generally. ii All names are pseudonyms.

iii As this study was completed over a number of months, the ages reported here reflect the ages of the children at the time of their participation in the interviews and photo tours.

iv Duplicate photographs were considered to be multiple photographs of the same person or object taken in sequence, without a significant change in the camera angle (this typically occurred when the children made use of the "burst" mode on the iPhone's camera, which enables the device to take multiple photographs in rapid succession when the shutter button is held).
} 